\title{
Impact of Soil Type, Moisture, and Depth on Swede Midge (Diptera: Cecidomyiidae) Pupation and Emergence
}

\author{
MAO CHEN AND ANTHONY M. SHELTON ${ }^{1}$ \\ Department of Entomology, Cornell University, NYS-AES, Geneva, NY 14456
}

\begin{abstract}
Environ. Entomol. 36(6): 1349-1355 (2007)
ABSTRACT Contarinia nasturtii (Kieffer) (Diptera: Cecidomyiidae), a common insect pest in Europe and a new invasive pest in North America, causes severe damage to cruciferous crops. Currently, many counties in Canada and the United States in which C. nasturtii has not been previously reported are at risk of being infested by C. nasturtii. Effectiveness of chemical control is limited, especially under high population pressure in fields, because the cryptic habits of C. nasturtii protect them from insecticidal sprays. Alternative management strategies against C. nasturtii that are needed to protect crucifers and soil management for the pupal stage were studied as one option. Six different types of soils (loam fine sand, fine sand, clay loam, muck, Chenango shale loam, and silt loam soil) were collected from commercial cabbage fields in New York and studied in the laboratory for their impact on C. nasturtii pupation and emergence. The results indicated that extremely wet or dry soils significantly hindered C. nasturtii emergence, regardless of soil type, suggesting that soil type alone may not be a major factor regulating $C$. nasturtii abundance. Optimal moisture content for C. nasturtii emergence varied for different soils. Most C. nasturtii pupated within the top $1 \mathrm{~cm}$ of soil. Furthermore, we found that $>5 \mathrm{~cm}$ of soil cover effectively reduced the emergence number and delayed the time of emergence. Based on these results, we suggest that soil manipulation (moisture content and cultivation practices) should be considered as an important component in an overall integrated pest management program for C. nasturtii.
\end{abstract}

KEY WORDS Contarinia nasturtii, soil type, moisture, pupation, emergence

Swede midge (Contarinia nasturtii Kieffer) (Diptera: Cecidomyiidae) is a gall-forming pest of cruciferous (Brassicaceae) plants and is widely distributed in Europe and southwestern Asia (Barnes 1946, Darvas et al. 2000). Host plants include canola, cruciferous weeds, and cultivated cruciferous vegetables such as broccoli, cabbage, and cauliflower (Hallett 2007). Plant damage results from larval feeding. Symptoms include misshapen plants with twisted stems, crumpled leaves, swollen growing tips, multiple heads, and the formation of galls on leaves and flowers (Bardner et al. 1971, Kikkert et al. 2002), which can severely reduce product quality and marketability. In Europe and Canada, C. nasturtii adults start to emerge from soil in mid-May (Thygesen 1966, Hallett and Heal 2001). Females lay eggs in clusters of 2-50 on the growing tips of plants. Larvae feed on actively growing stems, leaves, and flowers and then fall into the soil to pupate. In Europe and Canada, C. nasturtii may have two to five generations each year depending on soil moisture and temperature (Readshaw 1961, 1966, Hallett and Heal 2001).

In North America, C. nasturtii was first identified in Ontario, Canada, in 2000 (Hallett and Heal 2001). Subsequently, Canadian researchers launched a $C$. nasturtii survey in cruciferous crops, and good evi-

\footnotetext{
${ }^{1}$ Corresponding author, e-mail: ams5@cornell.edu.
}

dence was found that C. nasturtii occurred in nine counties in Ontario and one county in Québec in 2001. The number of infested counties in Canada increased from 18 in 2005 (CFIA 2005) to 49 in 2006 (CFIA 2006). In the United States, C. nasturtii adults were first captured in Niagara County, NY, by pheromone traps in September 2004, and C. nasturtii larvae were also identified at the same time (Kikkert et al. 2006). At the end of 2005 in New York, C. nasturtii infestations in Erie, Genesee, Monroe, Orleans, and Wyoming Counties were officially confirmed by the United States Department of Agriculture (Chen et al. 2007), based on morphological and molecular evidence. However, in 2005 and 2006, our laboratory confirmed by molecular analysis (Frey et al. 2004) that C. nasturtii was present in 13 more counties in New York (Allegany, Cattaraugus, Chautauqua, Chenango, Franklin, Jefferson, Lewis, Madison, Onondaga, Oswego, St. Lawrence, Suffolk, and Wayne) and 1 each in Massachusetts (Hampshire) and New Jersey (Sussex). It is obvious that this tiny pest is spreading in North America with dramatic speed. The main fresh cruciferous vegetables (broccoli, cabbage, and cauliflower) were grown on $\approx 121,400$ ha in the United States and had a total value of $\$ 1.2$ billion in 2003 (USDA-ERS 2005). Many of the major cruciferous vegetable growing regions in the United States are 
suitable C. nasturtii habitats (Ellis 2005). Olfert et al. (2006) predicted that C. nasturtii could potentially become established in all provinces of Canada and most of the United States based on soil moisture and other indexes. However, C. nasturtii population abundance varies greatly among and within different infested areas. For example, we found that the number of $C$. nasturti male adults captured per pheromone trap varied from 0 to $>400$ per card $\left(120 \mathrm{~cm}^{2}\right)$ in different cabbage fields from different farms and counties in the United States (unpublished data).

Soil abiotic factors, such as soil type and moisture content, are well known to have marked impacts on insects that spend part of their life cycles in soil (Macdonald and Ellis 1990, Pacchioli and Hower 2004, Shililu et al. 2004). For instance, significant impacts of soil types and moisture contents were found for pupating Bactrocera oleae (Gmel.) (Dimou et al. 2003) and eclosing Delia antiqua (Meigen) (Diptera: Anthomyiidae) (Tanaka and Watari 2003). Soil type and moisture content may be important factors for successful development of C. nasturtii (Hornig 1953, Readshaw 1961) and could be important factors regulating the population establishment and abundance of C. nasturtii in different infested areas. Thygesen (1966) studied the emergence of $C$. nasturtii in different soil types and found emergence was markedly earlier in light sandy soil than in heavy clay. In addition, Readshaw (1966) reported that soil moisture could affect $C$. nasturtii emergence and even cause dormancy after mature larvae were placed in soil with three to four different moisture levels. Readshaw (1968) suggested that it may be possible to achieve satisfactory control of $C$. nasturtii by simple cultural procedures, such as burying pupae too deeply in the soil to permit successful emergence. However, no soil manipulation studies have been done to assess the impact of different soil types and moisture levels on C. nasturtii pupation and emergence.

In this paper, we studied the impact of soil types collected from western New York State and different soil moisture levels on C. nasturtii pupation and emergence. Furthermore, we studied emergence patterns at different soil depths to simulate different cultivation practices that may be used for control of $C$. nasturtii.

\section{Materials and Methods}

Insect Culture. An initial population of C. nasturtii was kindly received from R. Baur from Switzerland (Swiss Federal Research Station for Horticulture, Wädenswil, Switzerland) in 2004 and was subsequently reared in a chamber under quarantine conditions at $22^{\circ} \mathrm{C}, \mathrm{RH} 75-78 \%$, and $16-\mathrm{h} \mathrm{L}: 8-\mathrm{h} \mathrm{D}$. The food plant was cauliflower, Brassica oleracea variety botrytis, Snow crown cultivar, with 8-10 true leaves. Cauliflower seeds were planted in a 128-cell tray every other week, and 3-wk-old seedlings were transplanted in pairs into pots $(13 \mathrm{~cm}$ diameter). Two pots of plants were put into 50 by 50 by $50-\mathrm{cm}$ wood-framed cages with netted sides containing $\approx 100$ adults, males and females $(\approx 1$ : 2 ), for mating and egg laying, and plants were changed daily. The growing tips of the plants were misted with tap water daily after larvae emerged from the eggs. The above ground parts were cut off $15 \mathrm{~d}$ after oviposition and placed on the soil to let older larvae pupate and emerge for the next generation.

Soil Type and Moisture Content. The soils were collected from farms in three counties (Niagara, Genesee, and Erie) in New York in 2005, using two different farms per county. The collections represented six different soil types: loamy fine sand, fine sand, clay loam, muck, Chenango shale loam, and silt loam (USDA 1972). At each farm, soil samples were collected from a depth of $0-20 \mathrm{~cm}$. All samples were returned to laboratory and air-dried $\approx 1$ mo in a screened house. Dried soil was ground using a pestle and mortar and sifted through a 2-mm sieve (Rowell 1994). Sifted soil was put into a hot air oven at $105^{\circ} \mathrm{C}$ for $24 \mathrm{~h}$ in preparation for making different soil moisture treatments (Ali-Shtayeh et al. 2002). After dried soil samples were removed from the oven, they were weighed before and after being saturated with distilled water. Moisture content was calculated as follows: moisture content $(\%)=[$ weight of distilled water/ (weight of saturated soil - weight of dried soil) ] $\times 100 \%$. Five soil moisture levels $(0,25,50,75$, and $100 \%$ ) were made for each soil type and used for the following studies.

Impact of Soil Type and Moisture Content on $\boldsymbol{C}$. nasturtii Emergence. Fifty C. nasturtii larvae (10 d old after oviposition) were moved with a tiny brush from the insect culture to the growing tip of an uninfested cauliflower plant $(\approx 4$ wk old after transplanting). The plants were kept in the rearing chamber for $2 \mathrm{~d}$ and cut at soil level. The growing tips of the plants were put on top of the different soils with different moisture contents in foam cups (diameter, $6 \mathrm{~cm}$; height, $15 \mathrm{~cm}$ ), and larvae were allowed to enter the soil to pupate. The cups with cauliflower growing tips were individually put into a Plexiglas cylinder cage (diameter, 12 $\mathrm{cm}$; height, $30 \mathrm{~cm}$ ) with one yellow sticky card $(4.5$ by $11 \mathrm{~cm}$ ) and kept in the rearing chamber after being weighed. The container with the soil cup and growing tip was weighed daily. Distilled water was added if there was any weight loss to keep the soil moisture constant until C. nasturtii started to emerge. Each soil type had the five different moisture content treatments, and each treatment had four replications. The sticky cards, the soil surface, and the bottom of each cage were checked daily, and the number of C. nasturtii adults emerged from different soil types was recorded until no more $C$. nasturtii adults emerged for $15 \mathrm{~d}$. The day of first emergence, emergence peak, and duration of emergence of $C$. nasturtii from different soil types and moisture contents were recorded. Male and female $C$. nasturtii were sorted and counted with the aid of a stereomicroscope at the end of this experiment. Also, the growing tip with C. nasturtii larvae on the top of each soil cup was checked for any larvae that remained or died in the tip.

Distribution of C. nasturtii Pupae in Different Soils. Based on the results of the experiment above, we found C. nasturtii adults started to emerge from all 
Table 1. Proportions of $C$. nasturtii adult emergence after larvae were allowed to pupate in different soil types with different moisture contents

\begin{tabular}{|c|c|c|c|c|c|}
\hline \multirow{2}{*}{ Soil type } & \multicolumn{5}{|c|}{ Moisture content (\%) } \\
\hline & 0 & 25 & 50 & 75 & 100 \\
\hline Loamy fine sand & $0 \mathrm{aB}$ & $38.5 \pm 3.5 \mathrm{aA}$ & $32.0 \pm 2.7 \mathrm{aA}$ & $33.6 \pm 14.4 \mathrm{aA}$ & $3.2 \pm 1.0 \mathrm{aB}$ \\
\hline Fine sand & $0 \mathrm{aB}$ & $40.0 \pm 4.1 \mathrm{aA}$ & $26.7 \pm 3.3 \mathrm{aA}$ & $31.2 \pm 1.3 \mathrm{aA}$ & $0 \mathrm{aB}$ \\
\hline Clay loam & $0 \mathrm{aB}$ & $38.7 \pm 5.5 \mathrm{aA}$ & $54.0 \pm 8.3 \mathrm{aA}$ & $44.4 \pm 5.9 \mathrm{aA}$ & $5.7 \pm 2.5 \mathrm{aB}$ \\
\hline Muck & $0 \mathrm{aB}$ & $23.5 \pm 0.7 \mathrm{aA}$ & $35.2 \pm 7.0 \mathrm{aA}$ & $43.4 \pm 0.7 \mathrm{aA}$ & $0 \mathrm{aB}$ \\
\hline Chenango shale loam & $0 \mathrm{aB}$ & $16.3 \pm 4.7 \mathrm{aA}$ & $37.2 \pm 1.3 \mathrm{aA}$ & $42.4 \pm 3.1 \mathrm{aA}$ & $1.2 \pm 0.8 \mathrm{aB}$ \\
\hline Silt loam & $0 \mathrm{aC}$ & $34.4 \pm 2.4 \mathrm{aB}$ & $24.3 \pm 2.3 \mathrm{aB}$ & $51.2 \pm 3.1 \mathrm{aA}$ & $2.8 \pm 1.7 \mathrm{aC}$ \\
\hline
\end{tabular}

Means \pm SE followed by different lowercase letters within a column or different capital letters within a row are significantly different (Fisher's protected LSD means separation test, $P<0.05)$.

different soils $>9 \mathrm{~d}$ after the growing tip was cut, and $50 \%$ moisture content was suitable for C. nasturtii pupation in each soil. Thus, $50 \%$ moisture content was used to study the distribution of C. nasturtii pupae in the different soils. Fifty C. nasturtii larvae (10 d after oviposition) were moved from the insect culture to a cauliflower plant's growing tip, kept in the rearing chamber for $2 \mathrm{~d}$, and cut and put on the soil surface of each cup with four replications. Experimental conditions were the same as above. The soil cup with the growing tip was removed from the cylinder cage $7 \mathrm{~d}$ before C. nasturtii were expected to emerge so insects would be in the pupal stage. Subsequently, the soil cup was sliced into 1-cm segments from the top to bottom, and each soil slice was examined under the microscope for C. nasturtii pupae. The growing tip on the top of each soil sample was checked for any larvae that remained or died in the tip.

Impact of Different Depths of Soil on C. nasturtii Emergence. Soil cups with 50\% moisture content were prepared as in the distribution experiment described above. Before the soil cup with a growing tip containing 50 C. nasturtii larvae was put into a cylinder cage, $0,2,5,10$, or $15 \mathrm{~cm}$ of $50 \%$ moisture content of the same type of soil was added to the top of each soil cup, respectively. This resulted in $C$. nasturtii larvae being buried under one of five different depths of soil with four replications. One yellow sticky card was placed in each cage and was checked daily as described above.

Statistical Analysis. Proportion of C. nasturtii emergence was calculated as follows: proportion emergence $(\%)=[$ number of emergence $/(50-$ number of larvae remained or died in growing tip) ] $\times 100$. Data on proportions of C. nasturtii emergence and $C$. nasturtii female adults were transformed by arcsine or arcsine square root to normalize the variance before statistical analysis, but untransformed means are presented. Effects of soil type, moisture content, and/or soil depth on C. nasturtii emergence and female proportion and emergence timing were analyzed by analysis of variance (ANOVA) using the general linear model (GLM) procedure. When a factor had a significant effect, comparisons were made within the factor using one-way ANOVA and Fisher protected least significant difference (LSD) means separation test (SPSS version 11.5 for Windows; SPSS, Chicago, IL). Distribution data of C. nasturtii pupae in different soil types were also analyzed by GLM procedure.

Table 2. Impact of soil types and moisture content on emergence parameters of $C$. nasturtii

\begin{tabular}{|c|c|c|c|c|}
\hline \multirow{2}{*}{ Emergence parameters (d) } & \multirow{2}{*}{ Soil type } & \multicolumn{3}{|c|}{ Moisture content (\%) } \\
\hline & & 25 & 50 & 75 \\
\hline \multirow[t]{6}{*}{ Days to first emergence $^{a}$} & Loamy fine sand & $10.8 \pm 0.3 \mathrm{bA}$ & $11.4 \pm 0.4 \mathrm{aA}$ & $11.8 \pm 0.5 \mathrm{abA}$ \\
\hline & Fine sand & $11.8 \pm 0.3 \mathrm{bA}$ & $11.75 \pm 0.3 \mathrm{aA}$ & $11.6 \pm 0.2 \mathrm{abA}$ \\
\hline & Clay loam & $11.3 \pm 0.3 \mathrm{bA}$ & $11 \pm 0 \mathrm{aA}$ & $11.4 \pm 0.3 \mathrm{bA}$ \\
\hline & Muck & $11.8 \pm 0.3 \mathrm{bA}$ & $12.2 \pm 0.6 \mathrm{aA}$ & $12.5 \pm 1.5 \mathrm{abA}$ \\
\hline & Chenango shale loam & $14.0 \pm 0.7 \mathrm{aA}$ & $12.4 \pm 1.0 \mathrm{aA}$ & $13.0 \pm 0.6 \mathrm{aA}$ \\
\hline & Silt loam & $11.8 \pm 0.3 \mathrm{bA}$ & $11.8 \pm 0.3 \mathrm{aA}$ & $11.6 \pm 0.2 \mathrm{abA}$ \\
\hline \multirow[t]{6}{*}{ Emergence peak } & Loamy fine sand & $13.0 \pm 0 \mathrm{abA}$ & $12.2 \pm 0.4 \mathrm{cdA}$ & $12.8 \pm 0.2 \mathrm{bcA}$ \\
\hline & Fine sand & $12.0 \pm 0 \mathrm{cA}$ & $11 \pm 0 \mathrm{cdA}$ & $12.0 \pm 0.3 \mathrm{cdA}$ \\
\hline & Clay loam & $12.7 \pm 0.7 \mathrm{abA}$ & $12.33 \pm 0.3 \mathrm{bcA}$ & $12.4 \pm 0.3 \mathrm{bcA}$ \\
\hline & Muck & $13.0 \pm 0.6 \mathrm{abA}$ & $13 \pm 0.4 \mathrm{abA}$ & $14.8 \pm 0.9 \mathrm{aA}$ \\
\hline & Chenango shale loam & $14.0 \pm 0.7 \mathrm{aA}$ & $14.0 \pm 0.6 \mathrm{aA}$ & $13.4 \pm 0.6 \mathrm{abA}$ \\
\hline & Silt loam & $12.0 \pm 0 \mathrm{cA}$ & $14.0 \pm 0.6 \mathrm{aA}$ & $13.0 \pm 0.2 \mathrm{bcA}$ \\
\hline \multirow[t]{6}{*}{ Emergence duration } & Loamy fine sand & $5.5 \pm 0.8 \mathrm{aA}$ & $5.8 \pm 0.8 \mathrm{aA}$ & $6.0 \pm 0.6 \mathrm{aA}$ \\
\hline & Fine sand & $4.75 \pm 0.7 \mathrm{aA}$ & $5 \pm 0.8 \mathrm{aA}$ & $5.0 \pm 0.7 \mathrm{aA}$ \\
\hline & Clay loam & $5.7 \pm 0.7 \mathrm{aA}$ & $5.0 \pm 1.0 \mathrm{aA}$ & $4.0 \pm 0.7 \mathrm{aA}$ \\
\hline & Muck & $4.5 \pm 0.8 \mathrm{aA}$ & $3.8 \pm 0.6 \mathrm{aA}$ & $5.3 \pm 1.5 \mathrm{aA}$ \\
\hline & Chenango shale loam & $3.5 \pm 0.5 \mathrm{aA}$ & $3.8 \pm 0.7 \mathrm{aA}$ & $4.2 \pm 0.5 \mathrm{aA}$ \\
\hline & Silt loam & $5.3 \pm 0.9 \mathrm{aA}$ & $6.0 \pm 0.8 \mathrm{aA}$ & $5.8 \pm 0.6 \mathrm{aA}$ \\
\hline
\end{tabular}

\footnotetext{
${ }^{a}$ Recorded from the day when cauliflower plants with C. nasturtii larvae were cut.

Means \pm SE followed by different lowercase letters within a column or different capital letters within a row are significantly different (Fisher's protected LSD means separation test, $P<0.05$ ).
} 
Table 3. Proportions of $C$. nasturtii female adults that emerged from different soil types with different moisture contents

\begin{tabular}{llll}
\hline \multicolumn{1}{c}{ Soil type } & \multicolumn{3}{c}{ Moisture content (\%) } \\
\hline $\begin{array}{l}\text { Loamy fine } \\
\quad \text { sand }\end{array}$ & $70.2 \pm 11.9 \mathrm{aA}$ & $71.5 \pm 12.6 \mathrm{aA}$ & $75.7 \pm 1.9 \mathrm{aA}$ \\
Fine sand & $67.5 \pm 16.3 \mathrm{aA}$ & $60.9 \pm 9.1 \mathrm{aA}$ & $47.7 \pm 4.7 \mathrm{cA}$ \\
Clay loam & $52.5 \pm 3.7 \mathrm{aA}$ & $65.9 \pm 5.7 \mathrm{aA}$ & $58.8 \pm 5.2 \mathrm{bcA}$ \\
Muck & $51.3 \pm 5.7 \mathrm{aA}$ & $78.7 \pm 10.5 \mathrm{aA}$ & $72.0 \pm 8 \mathrm{aA}$ \\
Chenango shale & $66.0 \pm 4.5 \mathrm{aA}$ & $67.6 \pm 12.5 \mathrm{aA}$ & $67.7 \pm 7.1 \mathrm{abA}$ \\
$\quad$ loam & & & \\
Silt loam & $63.8 \pm 3.0 \mathrm{aA}$ & $54.3 \pm 9.6 \mathrm{aA}$ & $41.3 \pm 0.8 \mathrm{cA}$ \\
\hline
\end{tabular}

Means \pm SE followed by different lowercase letters within a column or different capital letters within a row are significantly different (Fisher's protected LSD means separation test, $P<0.05$ ).

\section{Results}

Impact of Soil Type and Moisture Content on $C$. nasturtii Emergence. Emergence patterns of C. nasturtii were significantly affected by moisture content $(F=38.511 ; \mathrm{df}=4,91 ; P<0.001 ;$ Table 1$)$. Extremes of moisture contents ( 0 and $100 \%)$ significantly hampered $C$. nasturtii emergence, regardless of soil type. However, overall soil type $(F=1.682 ; \mathrm{df}=5,91 ; P=$ $0.147)$ and the interaction of soil type and moisture content $(F=0.540 ; \mathrm{df}=20,91 ; P=0.941)$ did not significantly affect $C$. nasturtii emergence (Table 1 ). Optimal moisture content for C. nasturtii emergence was between 25 and $75 \%$, varying with different soils. Impact of soil types on C. nasturtii emergence timing and female proportion was analyzed only for 25,50 , and $75 \%$ moisture contents, because of $<6 \%$ emergence in the extremes of moisture contents. The day of first emergence of C. nasturtii was significantly affected by soil type $(F=4.860 ; \mathrm{df}=5,60 ; P=0.001)$, but not by moisture content $(F=0.444 ; \mathrm{df}=2,60 ; P=$ $0.643)$ and soil by moisture interaction $(F=0.733 ; \mathrm{df}=$
10,$60 ; P=0.691$; Table 2). Similarly, emergence peak and duration of emergence were significantly affected by soil type $(F=8.785$; $\mathrm{df}=5,60 ; P<0.001$ and $F=$ $2.785 ; \mathrm{df}=5,60 ; P=0.026)$ but not by moisture content $(F=1.100 ; \mathrm{df}=2,60 ; P=0.340$ and $F=0.121 ; \mathrm{df}=2,60$; $P=0.886)$ or soil by moisture interaction $(F=1.127$; $\mathrm{df}=10,60 ; P=0.056$ and $F=0.613 ; \mathrm{df}=10,60 ; P=$ 0.797 , respectively; Table 2 ). As shown in Table 3 , the proportions of female $C$. nasturtii emerged from different soil types were significantly different $(F=$ $2.934 ; \mathrm{df}=5,60 ; P=0.02)$. However, the female proportion of C. nasturtii was not significantly affected by moisture content $(F=0.803 ; \mathrm{df}=2,60 ; P=0.453)$ or soil by moisture interaction $(F=1.610 ; \mathrm{df}=10,60 ; P=$ 0.126 ; Table 3).

Distribution of C. nasturtii Pupae in Different Soils. Soil type did not significantly affect distribution of pupae $(F=0.970 ; \mathrm{df}=5,72 ; P=0.446 ;$ Fig. 1$)$. More than $90 \%$ of pupae were found in the top $1 \mathrm{~cm}$ of soil $(F=1,352.198 ; \mathrm{df}=3,72 ; P<0.001)$. No $C$. nasturtii pupae were found in $>4 \mathrm{~cm}$ deep soil layers, regardless of soil type (Fig. 1).

Impact of Different Depths of Soil on C. nasturtii Emergence. Emergence of $C$. nasturtii was significantly reduced in deeper soil cover treatments $(F=$ 21.372; $\mathrm{df}=4,82 ; P<0.001$; Table 4). However, soil type $(F=1.116 ; \mathrm{df}=5,82 ; P=0.358)$ and soil by cover interaction $(F=0.936 ; \mathrm{df}=20,82 ; P=0.545)$ did not significantly affect $C$. nasturtii emergence. Soil type $(F=5.582 ; \mathrm{df}=5,73 ; P<0.001)$, soil cover $(F=94.091$; $\mathrm{df}=4,73 ; P<0.001)$, and soil by cover interaction $(F=$ 4.052; $\mathrm{df}=20,73 ; P<0.001$ ) significantly affected the day of first emergence (Table 5). Deeper soil cover also significantly delayed the emergence peak $(F=$ 82.796; $\mathrm{df}=4,73 ; P<0.001)$. The emergence peak of C. nasturtii was also significantly affected by soil type $(F=2.621 ; \mathrm{df}=5,73 ; P=0.031)$ and soil by cover

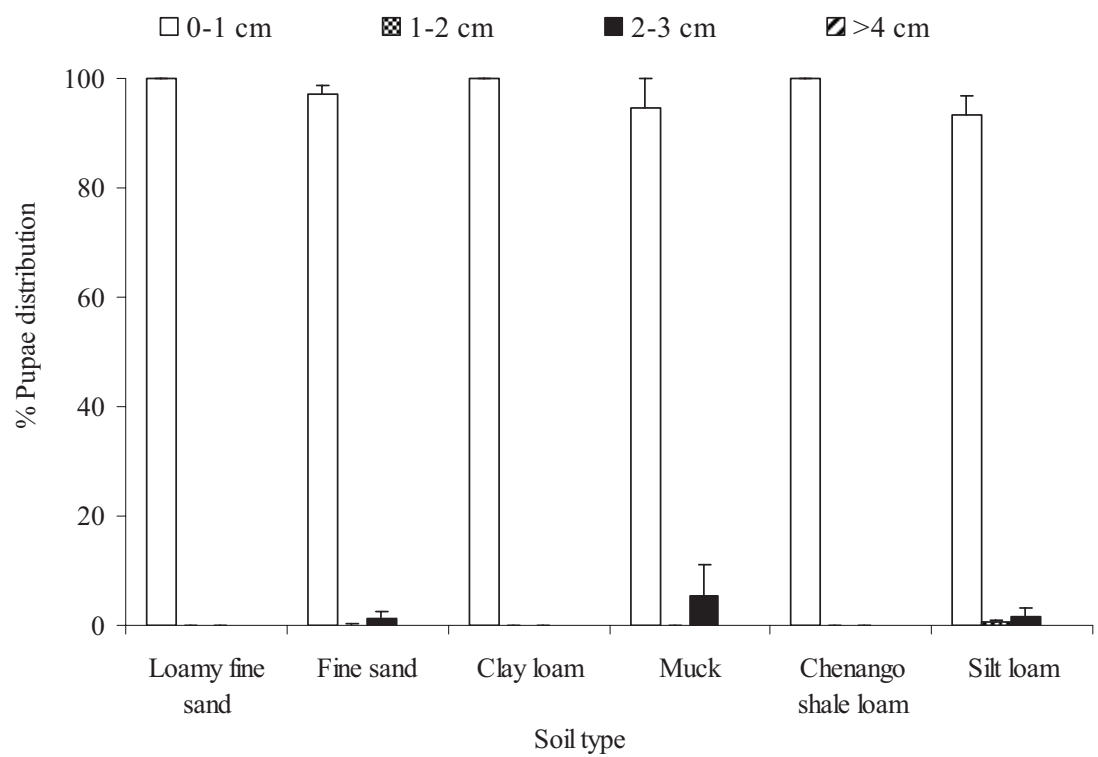

Fig. 1. Distribution of C. nasturtii pupae in soil after larvae were allowed to pupate in different soils. 
Table 4. Proportions of $C$. nasturtii adult emergence after larvae were allowed to pupate in different soil types under different depths of soil cover

\begin{tabular}{|c|c|c|c|c|c|}
\hline \multirow{2}{*}{ Soil type } & \multicolumn{5}{|c|}{ Soil cover $(\mathrm{cm})$} \\
\hline & 0 & 2 & 5 & 10 & 15 \\
\hline Loamy fine sand & $32.0 \pm 2.7 \mathrm{aB}$ & $39.3 \pm 4.4 \mathrm{aA}$ & $11.3 \pm 11.3 \mathrm{aBC}$ & $2.7 \pm 1.7 \mathrm{aC}$ & $2.3 \pm 1.2 \mathrm{aC}$ \\
\hline Fine sand & $26.7 \pm 3.3 \mathrm{aB}$ & $47.3 \pm 12.7 \mathrm{aA}$ & $2.7 \pm 1.4 \mathrm{aC}$ & $6.0 \pm 2.0 \mathrm{aC}$ & $1.0 \pm 0.7 \mathrm{aC}$ \\
\hline Clay loam & $54.0 \pm 8.3 \mathrm{aA}$ & $36.0 \pm 6.6 \mathrm{aB}$ & $12.7 \pm 3.5 \mathrm{aBC}$ & $15.7 \pm 5.7 \mathrm{aBC}$ & $0.3 \pm 0.3 \mathrm{aC}$ \\
\hline Muck & $35.2 \pm 7.0 \mathrm{aA}$ & $25.3 \pm 14.1 \mathrm{aAB}$ & $2.0 \pm 2.0 \mathrm{aB}$ & $1.3 \pm 1.3 \mathrm{aB}$ & $0.7 \pm 0.7 \mathrm{aB}$ \\
\hline Chenango shale loam & $37.2 \pm 1.3 \mathrm{aA}$ & $36.0 \pm 9.3 \mathrm{aAB}$ & $18.0 \pm 6.1 \mathrm{aAB}$ & $12.0 \pm 8.0 \mathrm{aAB}$ & $1.8 \pm 0.6 \mathrm{aB}$ \\
\hline Silt loam & $24.3 \pm 2.3 \mathrm{aAB}$ & $33.0 \pm 14.4 \mathrm{aA}$ & $16.7 \pm 6.4 \mathrm{aAB}$ & $9.6 \pm 8.1 \mathrm{aAB}$ & $1.7 \pm 0.9 \mathrm{aB}$ \\
\hline
\end{tabular}

Means \pm SE followed by different lowercase letters within a column or different capital letters within a row are significantly different (Fisher's protected LSD means separation test, $P<0.05)$.

interaction $(F=3.920$; $\mathrm{df}=20,73 ; P<0.001)$. Similarly, the emergence duration was significantly affected by soil type $(F=4.057$; $\mathrm{df}=5,73 ; P=0.003)$, soil cover $(F=24.101$; $\mathrm{df}=4,73 ; P<0.001)$, and soil by cover interaction $(F=3.431 ; \mathrm{df}=20,73 ; P<0.001)$. The proportion of female $C$. nasturtii adult emergence was not affected by soil type $(F=1.714 ; \mathrm{df}=5,58 ; P=$ $0.146)$, soil cover $(F=1.995$; $\mathrm{df}=4,58 ; P=0.107)$, or soil by cover interaction $(F=0.978$; $\mathrm{df}=20,58 ; P=$ 0.501; Table 6).

\section{Discussion}

Contarinia nasturtii, a common insect pest in Europe (Frey et al. 2004) and a new invasive pest in Canada (Hallett and Heal 2001) and the United States (Kikkert et al. 2006), causes severe damage to cruciferous crops. Currently, many counties in Canada and the United States in which C. nasturtii has not been previously reported are facing the threat of being infested by $C$. nasturtii (Olfert et al. 2006). Chemical insecticides showed promising control against $C$. nasturtii under laboratory conditions (Wu et al. 2006, Chen et al. 2007). However, under field conditions in Canada with high $C$. nasturtii population pressure, no synthetic insecticide, even when applied weekly, was able to control an endemic C. nasturtii population on broccoli (unpublished data). Alternative control methods against C. nasturtii are sorely needed to protect crucifers.

In this study, our results indicated that soil moisture content can significantly affect $C$. nasturtii emergence, regardless of soil type. Similarly, Hulthen and Clarke (2006) reported that soil moisture, especially the extremes of soil moisture, was a major pupal mortality factor of Bactrocera tryoni (Froggatt) (Diptera: Tephritidae) pupae in soil, whereas soil type (loamy sand, loam, sandy clay) had minor impact on pupal mortality. However, why extremes of soil moisture contents can effectively hamper $C$. nasturtii emergence is unclear. Readshaw (1966) reported that C. nasturtii larvae could remain quiescent (dormant) and construct spherical cocoons when entering dry sandy loam (8-15\% moisture content) and peaty clay soil $(\approx 43 \%$ moisture content) until the soils were thoroughly wetted. However, after $C$. nasturtii larvae in plant material were placed on top of the dry soil in our study, we observed that C. nasturtii larvae could still enter the soil but wrapped themselves with dry soil particles and became immobilized, instead

Table 5. Impact of soil types on emergence parameters of $C$. nasturtii under different depths of soil cover

\begin{tabular}{|c|c|c|c|c|c|c|}
\hline \multirow{2}{*}{$\begin{array}{c}\text { Emergence } \\
\text { parameters (d) }\end{array}$} & \multirow{2}{*}{ Soil type } & \multicolumn{5}{|c|}{ Soil cover $(\mathrm{cm})$} \\
\hline & & 0 & 2 & 5 & 10 & 15 \\
\hline \multirow{6}{*}{$\begin{array}{l}\text { Days to first } \\
\text { emergence }^{a}\end{array}$} & Loamy fine sand & $11.4 \pm 0.4 \mathrm{aC}$ & $12.7 \pm 0.3 \mathrm{abBC}$ & $11 \pm 0.6 \mathrm{cdC}$ & $13.5 \pm 2.5 \mathrm{bcB}$ & $18.5 \pm 0.5 \mathrm{cA}$ \\
\hline & Fine sand & $11.8 \pm 0.3 \mathrm{aD}$ & $12.3 \pm 0.3 \mathrm{bcC}$ & $14 \pm 0.3 \mathrm{aB}$ & $16.7 \pm 0.3 \mathrm{abAB}$ & $17.5 \pm 1.5 \mathrm{cdA}$ \\
\hline & Clay loam & $11.0 \pm 0 \mathrm{aC}$ & $11.3 \pm 0.3 \mathrm{cdC}$ & $12 \pm 0.6 \mathrm{bcBC}$ & $14.0 \pm 1.1 \mathrm{bcB}$ & $24 \pm 0 \mathrm{aA}$ \\
\hline & Muck & $12.2 \pm 0.6 \mathrm{aB}$ & $13.0 \pm 0 \mathrm{aB}$ & $13 \pm 0.3 \mathrm{abB}$ & $21 \pm 0.6 \mathrm{aA}$ & $21 \pm 0.7 \mathrm{bA}$ \\
\hline & Chenango shale loam & $12.4 \pm 1.0 \mathrm{aBC}$ & $12.3 \pm 0.3 \mathrm{bcBC}$ & $12.3 \pm 0.9 \mathrm{abcAB}$ & $15.0 \pm 1.0 \mathrm{bcA}$ & $16.7 \pm 0.7 \mathrm{dA}$ \\
\hline & Silt loam & $11.8 \pm 0.3 \mathrm{aC}$ & $12.3 \pm 0.6 \mathrm{bcC}$ & $12.0 \pm 1.0 \mathrm{bcC}$ & $16.3 \pm 2.5 \mathrm{bcB}$ & $21.0 \pm 0 \mathrm{bA}$ \\
\hline \multirow{6}{*}{$\begin{array}{l}\text { Emergence } \\
\text { peak }\end{array}$} & Loamy fine sand & $12.2 \pm 0.4 \mathrm{bD}$ & $15.3 \pm 0.3 \mathrm{aBC}$ & $12 \pm 0 \mathrm{aD}$ & $16.0 \pm 0 \mathrm{bcB}$ & $19.5 \pm 1.5 \mathrm{cdA}$ \\
\hline & Fine sand & $11.8 \pm 0.3 \mathrm{bcD}$ & $14.7 \pm 0.3 \mathrm{aC}$ & $14 \pm 0 \mathrm{aC}$ & $17.3 \pm 0.3 \mathrm{abAB}$ & $17.5 \pm 1.5 \mathrm{dA}$ \\
\hline & Clay loam & $12.3 \pm 0.3 \mathrm{bB}$ & $14.0 \pm 1 \mathrm{aB}$ & $14 \pm 2.5 \mathrm{aB}$ & $15.4 \pm 0.4 \mathrm{bcB}$ & $24 \pm 0.7 \mathrm{aA}$ \\
\hline & Muck & $13.0 \pm 0.4 \mathrm{abB}$ & $13.7 \pm 0.3 \mathrm{aB}$ & $13 \pm 0.3 \mathrm{aB}$ & $21 \pm 0.8 \mathrm{aA}$ & $21 \pm 0.3 \mathrm{bcA}$ \\
\hline & Chenango shale loam & $14.0 \pm 0.6 \mathrm{aC}$ & $13.5 \pm 0.5 \mathrm{aC}$ & $14.0 \pm 0 \mathrm{aC}$ & $16.0 \pm 0.6 \mathrm{bcB}$ & $18.0 \pm 0 \mathrm{dA}$ \\
\hline & Silt loam & $14.0 \pm 0.6 \mathrm{aB}$ & $14.8 \pm 0.8 \mathrm{aB}$ & $13.0 \pm 0.6 \mathrm{aB}$ & $16.3 \pm 2.5 \mathrm{bcA}$ & $21.5 \pm 0.5 \mathrm{bA}$ \\
\hline \multirow{6}{*}{$\begin{array}{c}\text { Emergence } \\
\text { duration }\end{array}$} & Loamy fine sand & $5.8 \pm 0.8 \mathrm{aAB}$ & $8.0 \pm 0.6 \mathrm{aA}$ & $1 \pm 0 \mathrm{cCD}$ & $3.5 \pm 2.5 \mathrm{bcBC}$ & $4.5 \pm 1.5 \mathrm{aB}$ \\
\hline & Fine sand & $5.0 \pm 0.8 \mathrm{aB}$ & $8.7 \pm 0.3 \mathrm{aA}$ & $1 \pm 0 \mathrm{cD}$ & $2.3 \pm 0.7 \mathrm{bcC}$ & $1.5 \pm 0.5 \mathrm{bcC}$ \\
\hline & Clay loam & $5.0 \pm 1.0 \mathrm{aB}$ & $8.0 \pm 2 \mathrm{aAB}$ & $8.7 \pm 0.9 \mathrm{aA}$ & $6 \pm 0.7 \mathrm{aAB}$ & $1 \pm 0 \mathrm{cdC}$ \\
\hline & Muck & $3.8 \pm 0.6 \mathrm{aB}$ & $6.7 \pm 1.2 \mathrm{aA}$ & $2 \pm 0 \mathrm{cBC}$ & $1 \pm 0 \mathrm{cdCD}$ & $2 \pm 0 \mathrm{bcBC}$ \\
\hline & Chenango shale loam & $3.8 \pm 0.7 \mathrm{aA}$ & $6.0 \pm 1.4 \mathrm{aA}$ & $4.7 \pm 1.9 \mathrm{bcA}$ & $4.3 \pm 0.3 \mathrm{abA}$ & $3.3 \pm 1.5 \mathrm{abA}$ \\
\hline & Silt loam & $6.0 \pm 0.8 \mathrm{aA}$ & $7.3 \pm 0.6 \mathrm{aA}$ & $6.7 \pm 2.3 \mathrm{abA}$ & $2.3 \pm 1.0 \mathrm{bcB}$ & $1.5 \pm 0.5 \mathrm{bcB}$ \\
\hline
\end{tabular}

${ }^{a}$ Recorded from the day when cauliflower plants with C. nasturtii larvae were cut.

Means \pm SE followed by different lowercase letters within a column or different capital letters within a row of each tested indicator are significantly different (Fisher's protected LSD means separation test, $P<0.05$ ). 
Table 6. Proportions of $C$. nasturtii female adults that emerged from different soil types under different depths of soil cover

\begin{tabular}{|c|c|c|c|c|c|}
\hline \multirow{2}{*}{ Soil type } & \multicolumn{5}{|c|}{ Soil cover $(\mathrm{cm})$} \\
\hline & 0 & 2 & 5 & 10 & 15 \\
\hline Loamy fine sand & $71.5 \pm 12.6$ & $74.0 \pm 7.8$ & $52.9 \pm 6.7$ & $50 \pm 50$ & $87.5 \pm 12.5$ \\
\hline Fine sand & $60.9 \pm 9.1$ & $54.2 \pm 8.7$ & $100 \pm 0$ & $100 \pm 0$ & $100 \pm 0$ \\
\hline Clay loam & $65.9 \pm 5.7$ & $59.8 \pm 12.2$ & $68.3 \pm 1.6$ & $71.6 \pm 3.8$ & $83.3 \pm 16.7$ \\
\hline Muck & $54.3 \pm 9.6$ & $83.1 \pm 9.0$ & $66.7 \pm 16.3$ & $100 \pm 0$ & $100 \pm 0$ \\
\hline Chenango shale loam & $78.7 \pm 10.5$ & $56.2 \pm 16.8$ & $54.9 \pm 9.4$ & $83.3 \pm 12.4$ & $83.3 \pm 14.4$ \\
\hline Silt loam & $67.6 \pm 12.5$ & $83.6 \pm 9.2$ & $70.7 \pm 15.9$ & $56 \pm 29.9$ & $58.3 \pm 8.3$ \\
\hline
\end{tabular}

Values are means $\pm \mathrm{SE}$.

No significant effect was found based on ANOVA using the GLM procedure $(P>0.05)$.

of burrowing into the soil, and died on top of the soil. Similarly, Ellis et al. (2004) found that Aethina tumida (Murray) (Coleoptera: Nitidulidae) larvae could not burrow into dry packed soils to pupate. Thus, we infer that no $C$. nasturtii emergence from the dry soils occurred because of larval or pupal death instead of a quiescent period. Further study is needed to explain why saturated soils also effectively reduced $C$. nasturtii emergence. Soil types did not significantly affect $C$. nasturtii emergence proportions instead of emergence timing in this study, indicating that soil type may not be a major factor for variations in abundance of $C$. nasturtii population in different areas in North America.

Proportions of $C$. nasturtii female adults were not significantly affected by the soil type, moisture level, or burial depth, and the interactions between soil type and moisture level or burial depth with one exception for soil type (Table 3). Some species in the Cecidomyiidae tend to produce families with nearly all siblings being the same sex, such as Cystiphora sonachi (Bermi) (McClay 1996) and Sitodiplosis mosellana (Géhin) (Smith et al. 2004). It is possible that C. nasturtii also can produce unisexual broods, although it has not been reported. Based on our results, it may be inferred that soil parameters do not have a significant impact of the $C$. nasturtii sex ratio. However, further experiments are needed to rule out the impact of possible unisexual broods on proportions of C. nasturtii female adults emerging from different soils.

We further showed that $>5$-cm-deep soil cover significantly reduced the proportion of adult emergence (Table 4) and delayed the time of emergence of $C$. nasturtii (Table 5), suggesting proper cultivation practices may effectively control $C$. nasturtii in the field. Voshedskii and Makhotkin (2002) reported that deep tillage decreased the number of Phorbia fumigata (Meigan) (Diptera: Anthomyiidae) emerging from soil by more than two-fold (from 61.7 to 23.8 flies $/ \mathrm{m}^{2}$ ), and a superficial soil cultivation decreased the number of Calliptamus italicus L. (Orthoptera: Acrididae) by 55$57 \%$. In another study, Haack et al. (2000) found that emergence of an exotic species, Tomicus piniperda $\mathrm{L}$. (Coleoptera: Scolytidae), was significantly reduced after being buried in different soils (sandy loam and loam), whereas soil types did not affect the emergence patterns. Franzmann et al. (2006) found that soil burial depth could significantly affect emergence of the sorghum midge, Stenodiplosis sorghicola (Coquillett) (Diptera: Cecidomyiidae). In the case of $C$. nasturtii larvae, it has been suggested that larvae might leave their spherical cocoons that were constructed under unfavorable conditions, move to the surface, and pupate in oval cocoons as if entering the soil for the first time under favorable conditions (Hornig 1953, Readshaw 1966). However, we did not encounter such a phenomenon nor could we find any date showing a pupa successfully changing from a spherical to oval shape in soil.

Soil manipulation has often been reported as a component of integrated pest management. For instance, the hatching rate of brassica pod midge, Dasineura brassicae (Winnertz) (Diptera: Cecidomyiidae), was reduced in a plowing/comb harrowing treatment (Buchs and Katzur 2004), and soil cultivation during the overwintering period caused up to $50 \%$ additional winter mortality of sawfly pupae (Barker and Reynolds 2004). Based on our results and previous studies, we suggest that soil manipulation practices, such as flooding fields during noncropping periods to achieve $100 \%$ soil moisture level and implementing cultivation practices to bury pupae, could be used as an important component to control C. nasturtii in the field.

\section{Acknowledgments}

We thank Y. M. Cheung and M. Sliwinski for assistance throughout this study and $\mathrm{H}$. Collins for helpful comments on an earlier draft of the manuscript.

\section{References Cited}

Ali-Shtayeh, M. S., A.B.B.M. Mara'i, and R. M. Jamous. 2002. Distribution, occurrence and characerization of entomopathogenic fungi in agricultural soil in the Palestinian area. Mycopathologia 156: 235-244.

Bardner, H. M., C. A. Edwards, M. K. Arnold, and J. P. Rogerson. 1971. The symptoms of attack by swede midge (Contarinia nasturtii) and the effects on yield of Swedes. Entomol. Exp. Appl. 14: 223-233.

Barker, A. M., and C.J.M. Reynolds. 2004. Do host-plant interactions and susceptibility to soil cultivation determine the abundance of graminivorous sawflies on British farmland? J. Agric. Urban Entomol. 21: 257-269.

Barnes, H. F. 1946. Gall midges of economic importance, vol. 1: gall midges of root and vegetable crops. Crosby Lockwood \& Son, London, UK.

Buchs, W., and K. Katzur. 2004. Cultivation techniques as means to control pests in organic oilseed rape production. Bull. OILB/SROP. 27: 225-236.

Canadian Food Inspection Agency [CFIA]. 2005. List of regulated countries and regulated areas within Canada 
for swede midge (http://www.inspection.gc.ca/english/ plaveg/protect/dir/smidgee.shtml).

Canadian Food Inspection Agency [CFIA]. 2006. List of regulated countries and regulated areas within Canada for swede midge (http:/ / www.inspection.gc.ca/english/ plaveg/protect/dir/smidgee.shtml).

Chen, M., J. Z. Zhao, and A. M. Shelton. 2007. Control of Contarinia nasturtii (Diptera: Cecidomyiidea) by foliar sprays of acetamiprid on cauliflower transplants. Crop Protect. 26: 1574-1578.

Darvas, B., M. Skuhrava, and A. Andersen. 2000. Agricultural and dipteran pests of the Palaearctic region, vol. 1. In L. Papp and B. Darvas (eds.), Contributions to a manual of Palaearctic Diptera. Science Herald, Budapest, Hungary.

Dimou, I., C. Koutsikopoulos, A. P. Economopoulos, and J. Lykakis. 2003. Depth of pupation of the wild olive fruit fly, Bactrocera (Dacus) oleae (Gmel.) (Diptera: Tephritidae), as affected by soil abiotic factors. J. Appl. Entomol. 127: 12-17.

Ellis, J. D., R. Hepburn, B. Luckman, and P. J. Elzen. 2004. Effects of soil type, moisture, and density on pupation success of Aethina tumida (Coleoptera: Nitidulidae). Environ. Entomol. 33: 794-798.

Ellis, S. E. 2005. New pest response guidelines: swede midge (http://www.aphis.usda.gov/ppq/manuals/).

Franzmann, B. A., J. D. Lloyd, and M. P. Zalucki. 2006. Effect of soil burial depth and wetting on mortality of diapausing larvae and patterns of post-diapause adult emergence of sorghum midge, Stenodiplosis sorghicola (Coquillett) (Diptera: Cecidomyiidae). Aust. J. Entomol. 45: 192-197.

Frey, J. E., B. Frey, and R. Baur. 2004. Molecular identification of the swede midge (Diptera: Cecidomyiidae). Can. Entomol. 136: 771-780.

Haack, R. A., T. R. Petrice, and T. M. Poland. 2000. Tomicus piniperda (Coleoptera: Scolytidae) emergence in relation to burial depth of brood logs. J. Econ. Entomol. 93: 342-346.

Hallett, R. H. 2007. Host plant susceptibility to the swede midge, Contarinia nasturtii (Diptera: Cecidomyiidae). J. Econ. Entomol. 100: 1335-1343.

Hallett, R. H., and J. D. Heal. 2001. First nearctic record of the swede midge (Diptera: Cecidomyiidae), a pest of cruciferous crops from Europe. Can. Entomol. 133: 713715 .

Hornig, H. 1953. The significance of C. nasturtii for swede cultivation with special reference to conditions in Schleswig Holstein. Z. Angew. Entomol. 35: 271-318.

Hulthen, A. D., and A. R. Clarke. 2006. The influence of soil type and moisture on pupal survival of Bactrocera tryoni (Froggatt) (Diptera: Tephritidae). Aust. J. Entomol. 45: $16-19$.

Kikkert, J. R., C. A. Hoepting, and A. M. Shelton. 2002. Swede midge (http://www.nysipm.cornell.edu/factsheets/ vegetables/cruc/sm.pdf)

Kikkert, J. R., C. A. Hoepting, Q. J. Wu, P. Wang, R. Baur, and A. M. Shelton. 2006. Detection of Contarinia nasturtii (Diptera; Cecidomyiidae) in New York, a new pest of cruciferous plants in the United States. J. Econ. Entomol. 99: $1310-1315$.

Macdonald, P. J., and C. R. Ellis. 1990. Survival time of unfed, first-instar western corn rootworm (Coleoptera:
Chrysomelidae) and the effects of soil type, moisture, and compaction on their mobility in soil. Environ. Entomol. 19: $666-671$.

McClay, A. S. 1996. Unisexual broods in the gall midge Cystiphora sonchi (Bremi) (Diptera: Cecidomyiidae). Can. Entomol. 128: 775-776.

Olfert, O., R. Hallett, R. M. Weiss, J. Soroka, and S. Goodfellow. 2006. Potential distribution and relative abundance of swede midge, Contarinia nasturtii, an invasive pest in Canada. Entomol. Exp. Appl. 120: 221-228.

Pacchioli, M. A., and A. A. Hower. 2004. Soil and moisture effects on the dynamics of early instar clover root curculio (Coleoptera: Curculionidae) and biomass of alfalfa root nodules. Environ. Entomol. 33: 119-127.

Readshaw, J. L. 1961. The biology and ecology of the swede midge, Contarinia nasturtii (Kieffer) (Diptera: Cecidomyiidae). PhD thesis, University of Durham, Durham, UK.

Readshaw, J. L. 1966. The ecology of the swede midge, Contarinia nasturtii (Kieffer) (Diptera: Cecidomyiidae). I. Life-history and influence of temperature and moisture on development. Bull. Entomol. Res. 56: 685-700.

Readshaw, J. L. 1968. Damage to swedes by the swede midge, Contarinia nasturtii (Kieff.), and a possible method of cultural control. Bull. Entomol. Res. 58: 25-9.

Rowell, D. L. 1994. Soil science: methods and applications. Longman Scientific \& Technical, Harlow, Essex, UK.

Shililu, J. I., W. B. Grueber, C. M. Mbogo, J. I. Githure, L. M. Riddiford, and J. C. Beier. 2004. Development and survival of Anopheles gambiae eggs in drying soil: influence of the rate of drying, egg age, and soil type. J. Am. Mosq. Control Assoc. 20: 243-247.

Smith, M.A.H., I. L. Wise, and R. J. Lamb. 2004. Sex ratios of Sitodiplosis mosellana (Diptera: Cecidomyiidae): implications for pest management in wheat (Poaceae). Bull. Entomol. Res. 94: 569-575.

Tanaka, K., and Y. Watari. 2003. Adult eclosion timing of the onion fly, Delia antiqua, in response to daily cycles of temperature at different soil depths. Naturwissenschaften 90: 76-79.

Thygesen, T. 1966. The swede midge (C. nasturtii). Investigations on bionomics and economic importance, together with control experiments. Tidsskr. Planteavl. 70: 179-197.

U.S. Department of Agriculture [USDA]. 1972. Soil survey of Niagara, Genesee and Erie County, New York. U.S. Department of Agriculture Soil Conservation Service, Cornell University Agricultural Experiment Station. U.S Government Printing Office, Washington, DC.

U.S. Department of Agriculture, Economic Research Service [ USDA-ERS]. 2005. Vegetables and Melons Year-book Tables. http://www.ers.usda.gov.

Voshedskii, N. N., and A. G. Makhotkin. 2002. Effect of soil cultivation on numbers of wheat fly and Italian locust. Zashchita I Karantin Rastenii 8: 24.

Wu, Q. J., J. Z. Zhao, A. Taylor, and A. M. Shelton. 2006. Evaluation of insecticides and application methods against swede midge (Diptera: Cecidomyiidae), a new invasive insect pest in the United States. J. Econ. Entomol. 99: 117-122.

Received for publication 6 June 2007; accepted 23 August 2007 